
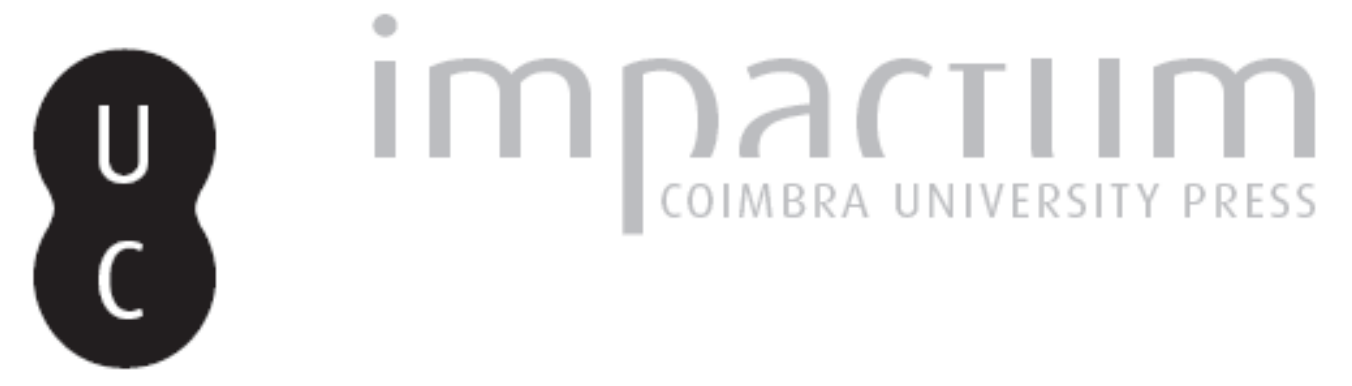

\title{
Reapproaching old buildings within the city
}

\section{Autor(es): $\quad$ Fortuna, Carlos}

Publicado por: Editorial do Departamento de Arquitetura

URL persistente:

URI:http://hdl.handle.net/10316.2/45183

DOI:

DOI:https://doi.org/10.14195/1647-8681_9_5

Accessed : $\quad$ 26-Apr-2023 08:46:40

A navegação consulta e descarregamento dos títulos inseridos nas Bibliotecas Digitais UC Digitalis, UC Pombalina e UC Impactum, pressupõem a aceitação plena e sem reservas dos Termos e Condições de Uso destas Bibliotecas Digitais, disponíveis em https://digitalis.uc.pt/pt-pt/termos.

Conforme exposto nos referidos Termos e Condições de Uso, o descarregamento de títulos de acesso restrito requer uma licença válida de autorização devendo o utilizador aceder ao(s) documento(s) a partir de um endereço de IP da instituição detentora da supramencionada licença.

Ao utilizador é apenas permitido o descarregamento para uso pessoal, pelo que o emprego do(s) título(s) descarregado(s) para outro fim, designadamente comercial, carece de autorização do respetivo autor ou editor da obra.

Na medida em que todas as obras da UC Digitalis se encontram protegidas pelo Código do Direito de Autor e Direitos Conexos e demais legislação aplicável, toda a cópia, parcial ou total, deste documento, nos casos em que é legalmente admitida, deverá conter ou fazer-se acompanhar por este aviso.

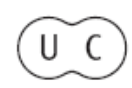



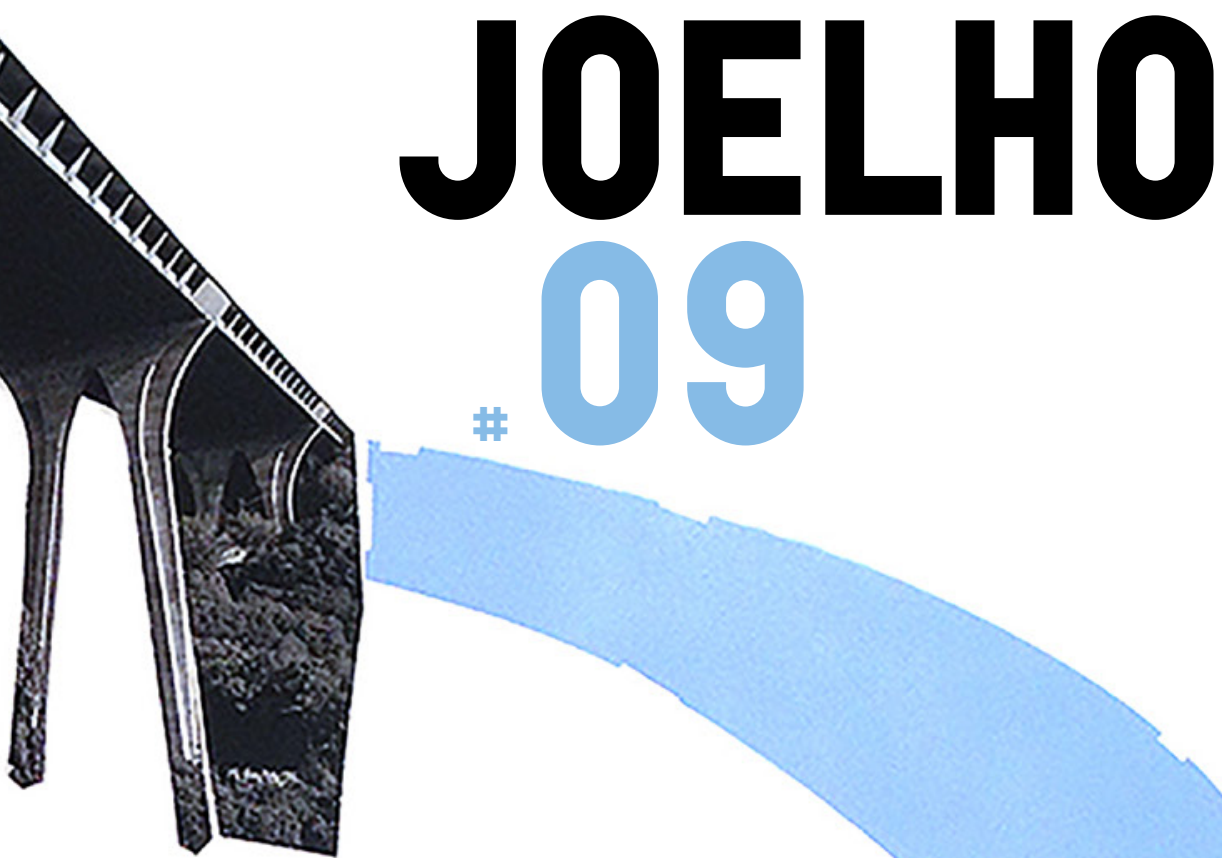

\section{REUSE OF MODERNIST BUILDINGS: PEDAGOGY AND PROFESSION}

Guest Editors:

Michel Melenhorst

Paulo Providência

Gonçalo Canto Moniz

ZUS: Elma van Boxel

and Kristian Koreman

Atelier do Corvo

Tilemachos Andrianopoulos

Albena Yaneva

Carlos Fortuna

Christian Gänshirt

Dieter Leyssen

Carolina Coelho

Anna Giovannelli

António Carvalho

Marta Peixoto

Els De Vos

and Eva Storgaard

Exhibition

$2^{\text {nd }}$ RMB Workshop, Coimbra

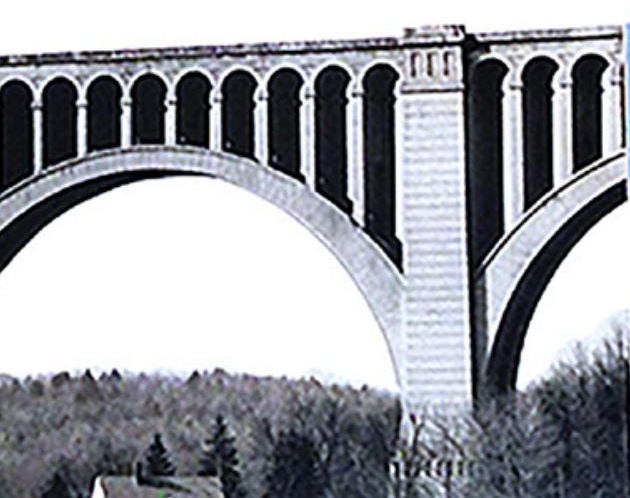




\section{Carlos Fortuna \\ Reapproaching Oİd Buildìngs within the $\mathrm{C}_{\text {ity }}$}

Centre for Social Studies,
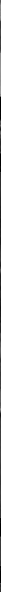
Suddenly for some reason I thought of Brasilia. The city of Brasilia was inaugurated in 1960. It was a perfect multidisciplinary exercise of harmonization between the urban planner (Lúcio Costa), the architect Óscar Niemeyer), and the landscape artist-architect (Roberto Burle Marx). Moreover, Brasilia was a typical construction of a city by the conquest of the open space made of sheer optimism, the triumph of talent over doubt and of the audacity over pessimism (Gorelik, 2005).

This reference to Brasilia serves as a sort of epigraph with which I will unravel some of my loose topics about the role of old buildings in reapproaching the contemporary city. I have never addressed specifically a journal for architects, city planners, or urban designers. On the contrary, I am far more used to deal with urban issues for groups of social scientists, sociologists, like myself, historians, anthropologists, geographers, and so forth. Here I am anyway, trying to address the issue of buildings and their possible reuses upon an interdisciplinary view, counting on your benevolence.

I organized the paper as a set of topics relatively autonomous. The first topic is precisely the interdisciplinary standpoint that I believe should prevail in such inquiry. Not exactly, the one mentioned above concerning the close relationship between the creators of Brasilia, but one that involves other not so obvious disciplinary proximities such as those with the social sciences.

In a recent paper, I have made a plea for "other views" concerning the interpretation of the city and the urban environment (Fortuna, 2012). It was a plea for scholars of the city to open the boundaries of their disciplines to other contributions. My argument was doubleedged: on the one hand, the need to look at the city's historical culture and tradition to better understand its changes over time; on the other hand, the need to recognize how it is transformed every day as a result of infrastructural interventions, especially led by urban architects and city planners.

Learning how to work together with others is the basis of any interdisciplinary work. However, for interdisciplinarity to be efficient, one cannot surrender the philosophical principles, theories and methods of our own discipline. In other words, disciplines remain essential to delineate a problem and try to design a possible response to it. That is so say disciplines are essential to ask the starting questions. When it comes to try to answer those questions and take action, each discipline needs to know the extension to which it could possibly combine and incorporate contributions coming from adjacent areas of thought and reflection. That is the above-mentioned audacity present upon the original design of Brasilia. In short, the discipline helps to ask the questions whereas interdisciplinarity becomes critical to provide adequate answers and encompass wider solutions.

Another way to deal with interdisciplinarity is to continuously expanding the original premises of our major area. Take the example of urban sociology. Broadly speaking, such discipline remains largely
Frontispiece Marcel Gautherot, "Vista aérea da Praça dos Três Poderes", Brasília, 1960. Instituto Moreira Salles 
dependent on canonical considerations made at the end of the $19^{\text {th }}$ century derived from the experiences of the great industrial metropoles of the Western world, i.e. mostly London, Manchester, Paris, and Berlin. Today, the discipline faces the need to renew itself in order to avoid analyzing the contemporary city in the light of those traditional, say conventional and outmoded visions. This affects the accuracy of the disciplinary work as a whole. For instance, there is still no suitable set of concepts or body of theories adequate to understand autonomously and not as a sort of mirror-like metropolitan theories the workings of small - and medium-sized cities, which account for over $2 / 3$ of the world's population. Similarly, urban sociologists are largely unprepared to grasp fully the postcolonial city, as little do we know of the so-called "other cities" located in the non-Western contexts of Africa, Asia, and even Latin America. The interdisciplinary calls for an ever-present recreation of our basic modes of inquiry and the ability to trespassing disciplinary boundaries (Mendieta, 2001; Amin \& Graham, 1997; Bell \& Jayne, 2006).

I believe that both in practice and in teaching architecture and urbanism are in a similar situation and are ready to open their views to outside readings and contributions. In fact, these disciplines are quite willing to dialogue with other narratives such as the arts, engineering, environmental sciences as well as social and human sciences, without, however, losing the bulk of their body of disciplinary knowledge and methods and enter a wider archipelago of correlate areas of knowledge.

A second topic that I would like to bring about when considering the role of old buildings in the urban fabric has to do with the relation of cities to history. Coming back to Brasilia, this city is often viewed as a city without history. Nevertheless, the history of this city takes the form of the national history of Brazil, which, somehow, appears repeatedly in the daily workings of such tropical metropolis.

Let me clarify this by mentioning two different ways to look at urban history of locales. One sees history primarily as a tool to help understand the present and the future of urban settings. In this sense, buildings, especially old buildings, become crucial to grasp the current local urban environment as well as to think of the cities yet to come. As a well-known Malaysian architect has argued, "a city without old buildings is like a man without memory" (Biswas, 2000, p. 131).

The other way to see the city in relation to history records people, events and places of value for their own sake and calls for the local history to be read, or taken care of, by the trajectories of these very same people's actions and events. In this sense, neither places nor buildings alone nor the action going in between them, cannot remain off the architectural concern.

Let me go a further in this. Claude Lévi-Strauss (1955, p. 157), writing about the cities of the so-called "New World", made some remarks about the way the new cities of southern Brazil were totally devoid of memory and moved swiftly from their unusual "freshness" to 
an inescapable "decrepitude". To the well-known Belgian ethnologist, everything happened as if cities had been submitted forcefully to a speedy outward rhythm of evolution, imposed upon their growth and mode of organization. Lévi-Strauss's description reminds another narrative on how New York City appears to be the least loved of any of the North-American cities. "Why should it be loved as a city?" asks the commentators who make their point by saying,

A man born in New York forty years ago finds nothing, absolutely nothing of the New York he knew. If he has the chance to stumble upon a few old houses, not yet leveled, he is fortunate. But the landmarks, the objects, which marked the city to him, as a city, are gone. (Burns, Sanders and Ades, 1999, p. 71).

Both the built environment and the human action are decisive for the New York ever-changing trajectories and physical arrangements. So, the question remains, do we have to keep old buildings to love cities, understand their past memories, and to figure out their possible futures? Or else, is it the case that "old buildings must die", as asked in a recent intriguing book (Cairns and Jacobs, 2014)?

In this line of reasoning let me briefly refer to old buildings within the urban landscape, by mentioning the famous American journalist and critic Jane Jacobs who gave a straightforward answer to maintenance/conservation of old city buildings. She was very much in favor of the preservation of (some) old buildings and the antique neighborhoods. Jane Jacobs did not mean the preservation of old buildings as museum-like structures. To her robust support for policies that would enable neighborhoods to mingle buildings of various ages and conditions, Jane Jacobs associated policies for the preservation and rehabilitation of the inner city social dynamics, namely the social life of streets and the enjoyable sights of neighbourhoods. "Cities, she wrote, need old buildings so badly it is probably impossible for vigorous streets and districts to grow without them" (Jacobs, 2000 [1961], p. 200).

This was part of Jacobs' well-known battle against what she took as the menace of destruction inscribed in Robert Moses' plan for her beloved Greenwich Village and Hudson Street, in downtown Manhattan. For Jacobs (2000 [1961], p. 207), buildings are seldom insulated entities and hence should be an integrative part of whatever "ingenious adaptation of old quarters", to keep their palimpsest-like historical structure.

Working as insulated entities are the typical iconic constructions of star architecture. As a rule, iconic buildings emerge as structures separated from the surrounding spatial context and obey to other principles of creation. Landmark structures are instrumental to promote an image of urban success or recovery from urban decline. Many cities experience some version of such "edifice complex" (Sudjic, 2016), as a strategy for exuberance and international promotion worldwide. Iconic 
buildings function as metaphorical aspects of architecture and their atypical form stands for a narrative of difference and urban creativity, which provides meaning to the whole city.

Designed to celebrate prestigious political occasions or events, such as the European Cultural Capital or the Olympics, these singular constructions seem to be built forever. Moreover, due to their representational and symbolic role, they seldom follow the traditional pre-modernist relationship that subordinated the urban form to the spatial context. Disconnected from space those buildings are not properly part of the urban stuff (streets, transportation systems, sidewalks, subterranean passages, fountains, street trees, etc.) and stay apart. Iconic buildings supplant then the contextual materiality of space to create a singular aesthetical landscape vital for contemporary urban societies (Glaeser, 2011; Livesey, 2004, pp. 17-23).

Aside this unique city markers, the exceptionalism of some renowned architects is also lent to other projects, such as prestigious corporate offices, conference centers, conspicuous cultural ensembles of art galleries, opera houses and so on (Short, 2004, pp.72-3). Ever since their American origin in 1889, skyscrapers are also a token within the unfolding of this symbolic architecture. Just as the impressive West European medieval cathedrals and palaces were to show the wealth and power of religion and of the elites, skyscrapers today are emblematic of a glassy architectural lure and suggest the power of global finance as the driving force of present-day capitalism. The emblematical architecture is a crucial dimension of what Deyan Sudjic (2016) calls The Language of Cities.

The fact, however, is that buildings are not artifacts similar to other disposable goods. As they fall out of time, buildings remain tenaciously present in the place, and cannot be put away like any other outdated object (Scalan, 2005, p. 111). Leaving aside time-specific and ephemeral constructions such as exposition edifices, buildings - especially those intended for working classes housing as in Friedrich Engels' Manchester lasting in average only some forty years (Engels, 1968, pp. 69-71) - deal with time limits and are "not built with longevity in mind" (Cairns and Jacobs, 2014, p. 111).

I would like to argue that the issue of the possible re-uses and rehabilitation or destruction only marginally concerns iconic buildings of whatever nature and is more adequate to think of the future of typically residential buildings or administrative structures and industrial complexes.

Some examples of the construction of poor quality and ruinous residential clusters, located in general in the outskirts of large cities, led to environmental and planning atrocities whose solution has pointed to irremediable implosion. The 1956 Pruitt-Igoe project, in St. Louis (Missouri - USA), designed by the celebrated architect Minoru Yamasaki, who also designed the New York World Trade Center, is an archetypal case in point. Its demolition occurred only one and a half 
decades after the construction of the 33 identical towers of 11 stories each, remains hitherto an impressive denunciation of the urban fiasco to which the city building process is subject (idem, 23). Other similar cases are the Cabrini-Green Homes (Chicago), the Ballymun Tower blocks (Dublin), or the Bijlmermeer borough (Amsterdam).

Many other no less famous inconsistencies have been accurately labelled real planning disasters (Hall, 1980). It should be mentioned here the attempts being made to supposedly overcome this preservation-demolition dichotomy and escape the logic of "programmed obsolescence" of low and middle-class buildings. I am thinking of some quite sensitive attempts to overcome the highly precarious housing of shadow cities, shantytowns, slums and favelas that punctuate the peripheries of the great majority of global South metropoles brought about by the uncontrolled expansion of colonial and post-colonial capitalism.

The most recent speculative investment towards the built environment in these regions brings private international capital, often in coalition with public investment, to build entirely new cities not to rehabilitate old ones and still less to vanish deprived slums. Examples include the African experiences of Appolonia City of Light (Ghana), Kilamba (Angola), Eko Atlantic (Nigeria), or New Cairo City (Egypt). The messy problems associated with the urban and social landscapes gets a still messier would-be solution as they turn to these new urban enclaves for the urban middle-classes. The "double cities", as Robin Murray calls them, are ready-made cities or, as I see them, sordid placeless places with no social content, nor urban history or memory whatsoever. They are supposed to become "urban" and function as "platforms for experiments in the production, ordering, and marketing of global excess in the midst of urban neglect and deprivation" (Murray, 2015, p. 93).

This is a sort of anticipated future disasters inflicted upon the environment and the urban. In fact, the "double cities" remind the "obsolete futures" and "ruins in reverse" enunciated by the legendary land artist Robert Smithson (1967, p. 54-55) when pointing to any "zero panorama" in which

buildings don't fall into ruin after they are built but rather rise into ruin before they are built. This anti-romantic mise-en-scène, he continues, suggests the discredited idea of time and many other "out of time" things".

Such incongruent and cynical urbanism is exactly what sustains the critique addressed to city builders, architects included, for aggravating the city's preexisting sociocultural discontinuities. A possible line of action is brought to us by Richard Sennett's (2018) recent Building and Dwelling. For the sociologist and urbanist the whole issue should link, on the one hand, the city's physical structure of the city (the ville) and, on the other hand, its sociopolitical dynamics (the cité). The author 
relates the former to the technical arrangements of the city spaces and infrastructures and involves architects and other "city makers" (urbanists, urban planners, engineers and so on), who act selectively, with no claim for global harmony. The latter points towards the mix of urban life, social rights and the citizens' social uses of space, and their professional action is a powerful dispositive to accomplish historical and cultural cohesion.

What is at issue for Sennett is the need to articulate these two colliding dimensions so that an "open" and democratic city can be envisaged. Along his review of various conflicting one-sided views of the problem throughout the modern urban thought, Sennett's uneasiness turns towards to the responsibility of architects and urbanists, whenever they privilege the ville and completely ignore the cité. On the other hand, the disconnected city can also be fruit of the insistence on the public social dimension without taking into account the constraints or the possibilities resulting from the materiality of the urban space. All in all, Sennett despises the mutual marginalization of perspectives: either the political and social vision or the architectural and urbanistic view. Both architects and town planners have been judged severely by Sennett to whom practitioners of unilateral visions of the urban should prevent themselves of working for the dominant international building lobbies and cause extreme damages do built environment.

Insofar the old buildings reuses or demolition is concerned my reading of Sennett goes along with Jane Jacobs' arguments, as well as with other writers of the sociocultural realm as Sharon Zukin (2010) or Suzanne Hall (2012). They all link buildings to the whole historical and cultural urban settings, always avoiding their utmost dis-affiliation with the historical and social urban atmosphere.

This may sound very much an old-school debate. It almost brings back to the late nineteenth century dispute between John Ruskin and Viollet-le-Duc. That is not my intention at all. I would rather go further on this point by opening up a final topic about the relationship of architecture to the reinvention or the imagination of a new urban environment.

By 1911, the German sociologist Georg Simmel (1911), whose death occurred exactly 100 years ago in 1918, wrote a curious text about the ruins. There he made very kind considerations about what he named the "art of architecture" and the architects themselves as holders of the supreme ability of leaving profound marks in nature, something that other artistic expressions (painting, music, dance...) are unable to do. I want to point out this ability of architecture to draw and redraw the (physical/structural) future of our cities.

To me, the "art of architecture" shows no obsession with the past whatsoever and appears very much future oriented. Nowadays, after the disappearance of the modernist fantasies, architects share with social 
scientists the ability to help read buildings and cities as transformable and transitory in nature, just like Simmel's ruins are continuously submitted to the vicissitudes of the passing time.

I'll be giving an example. I use to bring students of my cities and citizenship course to get acquainted with Kischo Kurokawa's Capsular Tower in Tokyo as one example of would-be architecture for future cities, that is, a mobile and flexible architecture, largely dependent upon the prefabrication modular processes of the late fifties.

The Capsular Tower works as metabolist architecture, aimed at the configuration of buildings totally adapted to current individualism. As such, the building functions as a biological analogy meant to replace the orthodox modern architecture, and to permit buildings and cities together to be subject to normal biological process of cycles of change, constant renewal and simultaneous ruination of organic tissues.

For Kurokawa, the capsular architecture contributes to a freer society, moving around the single individual and his/her mobility. $\mathrm{He}$ sees continuous migration and single-persons families as a symptom of the disintegration of the modern society. Hence, for Kurokawa the new city - which he calls the metapolis - works as a sort of anchorage of moving isolated individuals looking for temporary shelter. That is the bottom-line philosophy of the capsule, i.e., the future "dwelling of the Homo Movens". In the metapolis, the public space as such is to be replaced by a multitude of capsular spaces (homes, hotels, universities, department stores, terminals, automobiles). No more dense and crowded streets, as the streets are somehow brought inside the capsules.

I cannot avoid thinking provocatively of the possible similarity of this Kurokawa's imagined post-urban world with some other famous attempts to redesign the urban in a way that barely resembled anything that would normally be termed "city". So this allows asking for any possible resemblances between this capsule world and Fourier's phalanstery? Or with Ebenezer Howard's Garden city? Or Arturo Soria's Linear City? Or Frank Lloyd Wright's Disappearing City and Broadacre City, or, finally, Le Corbusier's Ville Radieuse?

I believe Kurokawa was reacting to the very negative visions of the post-modern city, just like Frank Lloyd Wright reacted to the negative views of the American city of the early 1930's. In the literature concerning the 1930's typical American city was evoked as

... too big, too noisy, too dusky, too dirty, too smelly, too commercial, too crowded, too full of immigrants... too pushy, too mobile, too fast, too artificial... (White and White, 1962, p. 222).

By and large these characteristics apply to Kurokawa' Tokyo to which he wanted the Tower model to provide redemption. As a metabolic object, however, the Tower soon entered a process of "natural" aging and obsolescence. It is quite thought demanding the evaluation of 
Kurokawa's Tower made by Rem Koolhaas and Hans Ulrich Obrist. For these commentators, the building is actually in a very bad shape and its vulnerability intensifies by the obsolescence effect of the then novel materials used in the construction (Koolhaas and Obrist, 2011, apud Cairns and Jacobs, 2014, p. 121). Such evaluation goes along with the comments made by a New York Times journalist who wrote about the Capsular Tower

Corridors smelled of mildew. Some tenants had taped plastic bags to their door frames to catch leaks, and many of them were bulging with gray water. At a point - he continues - a tenant [showed me] ... chunks of concrete off from the corner of one of the capsules. (Ouroussof, 2009, cited in Cairns and Jacobs, 2014, p. 121).

Apparently, Kurokawa's Tower remains standing only because "financial malaise" has meant the residents are, as yet, unable to find a developer to demolish the building and redevelop the site. To be sure, the splendor announced by the futuristic Tower gave way to a deceiving vision. Whether it should be demolished or rehabilitated and preserved is a question that remains to be answered.

From a socio-political standpoint, demolishing a building, in a democratic society, takes a long time to decide. We are not living in Mussolini's regime and the dictator most-celebrated passion for "his majesty the pick" (Kostov, 1992, p. 270). Today, such decisions are not taken in isolation and, time and again, what appears to be the end of a given building story may in fact turn into a larger brand-new urban redevelopment and regeneration matter.

Demolishing or imploding a building may at first seem to be a handy single solution. However, it usually becomes quite a complex decision, involving various social actors. Take the Coutinhos building (a specific local case in the northern city of Viana do Castelo, Portugal) and we certainly agree that more than taking too much time to implode, this building deemed to be levelled, continues to be used regularly and engender a variety of emotions. It is seen as the home by some, or is resentfully tolerated by others, whereas still others (actual tenants) complain bitterly about the drain of their economies.

Demolishing, imploding or, for that matter, rehabilitating a building remains a rather good example of a complex decision about the city and what to do about old or decaying buildings, to not to say old and decaying neighborhoods altogether. Yet, the nicest side of it is that it suggests a possible challenging subject matter for an interdisciplinary research, bringing together architecture and sociology and other social sciences.

My conclusion then goes as to argue that we are willing to live side by side with obsolescence and decadency. This is quite a challenge for those living in an old country like Portugal. We are learning how to live with buildings and cities that remain in place to be sure, although often out of their social time. To think about the complexity of their possible 
futures is, doubtless, one of the best contributions to hopefully expect from the architects... and the social scientists as well.

As with the construction of Brasilia, such interdisciplinary common research needs to be sustained with much optimism, hope and audacity above all.

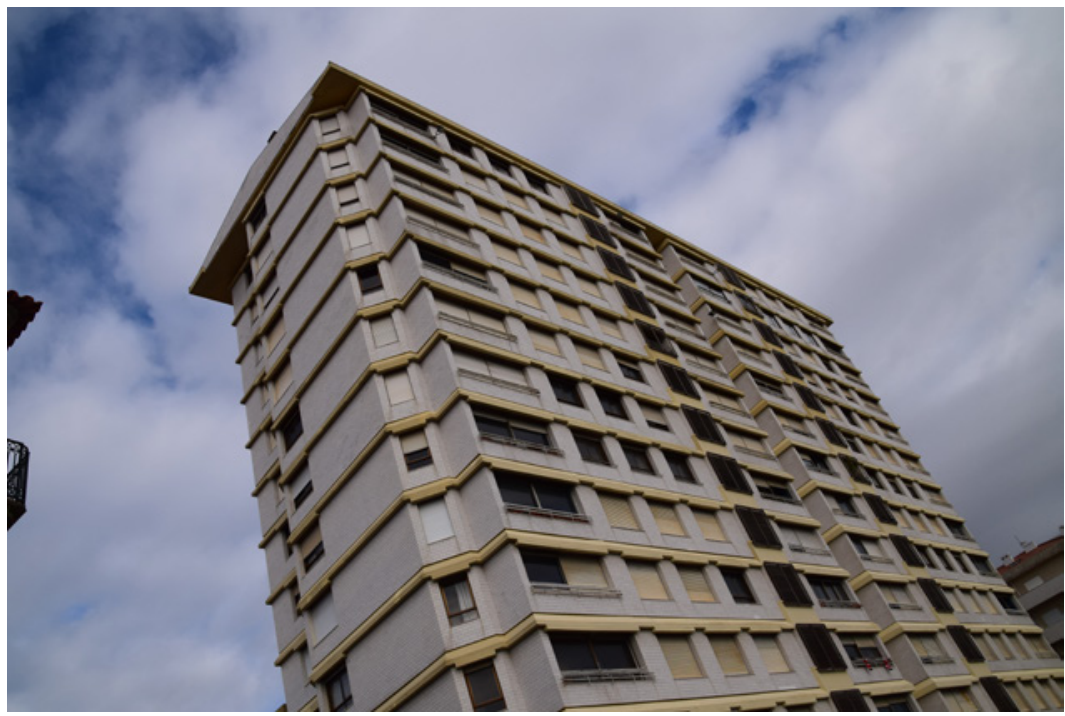

\section{References}

Amin, A., Graham, S. (1997), The ordinary city. In Transactions of the Institute of British Geographers, 22 (4), pp. 411-429.

Bell, D., Jayne, M. (eds.) (2006), Small cities. Urban experience beyond the metropolis. Oxford and New York: Routledge.

Biswas, R. K. (2000), Kuala Lumpur. Bigger, faster, better. In B. R. Kumar (ed.), Metropolis Now! Urban Cultures in Global

Cities. Wien and New York: Springer-Verlag.

Burns, R., Sanders, J., Ades, L. (1999). New York. An Illustrated History. New York: Alfred A. Knopf.

Cairns Stephen, C., Jacobs, J. J. (2014). Buildings must die. A preverse view of architecture. Cambridge (Mass.) and London: The MIT Press.

Engels, F. (1968 [1845]). The condition of the working class in England. Stanford: Stanford University Press.

Fortuna, C. (2012), In praise of other views. The world cities and the social sciences. lberoamerica. 45, pp. 137-152.

Glaeser, E. (2011). Triumph of the city. Oxford: Macmillan.
Gorelik, A. (2005). Das vanguardas a Brasilia. Cultura urbana e arquitectura na América Latina. Belo Horizonte: Editora UFMG.

Hall, P. (1980). Great Planning Disasters. Berkeley and Los Angeles: University of California Press.

Hall, S. (2012). City, street and citizen. The measure of the ordinary. London and New York: Routledge.

Koolhaas, R. Obrist, H. U. (2011). Project Japan. Metabolism Talks. Cologne: Taschen.

Kostov, S. (1992). The city assembled. The elements of urban form through history. London: Thames \& Hudson.

Lévi-Strauss, C. (1955). Tristes Trópicos. Lisboa: Edições 70.

Livesey, G. (2004). Passages. Explorations of the contemporary city. Calgary: University of Calgary Press.

-

Mendieta, E. (2001). Invisible cities. A phenomenology of globalization from below. City, 5 (1), pp. 7-26.

Murray, M. J. (2015), 'City Doubles'. Re-urbanism in Africa. In F. Miraftab, D. Wilson, Salo, K. (eds), Cities and inequalities in a global neoliberal world (92-109). New York: Routledge.
Fig. 2 Coutinho building in Viana do Castelo, photo by the author
Ouroussof, N. (2009), Future vision banished to the past. In New York Times (6 July).

Scalan, J. (2005). On Gabage. London: Reaktion.

-

Sennett, R. (2018) Building and dwelling; Ethics for the city. Milton Keynes: Allen Lane. Short, J. R. (2004). Global Metropolitan. Globalizing cities in a capitalist world. London: Routledge.

Simmel, G. (1959 [1911]), The Ruin. In G. Simmel et al., K. H. Wolf (org). Essays on sociology, philosophy and aesthetics (259-266). New York: Harper.

Smithson, R. (1967), A tour of the monuments of Passaic, New Jersey. Artforum, VI (4), pp. 52-57.

Sudjic, D. (2005). The edifice complex. How the rich and powerful shape the world. London: Penguin.

Sudjic, D. (2016). The language of cities. Milton Keynes: Penguin Books.

White, M., White, L. (1962), The intellectual and the city. From Thomas Jefferson to Frank Lloyd Wright. Cambridge (Mass.): Mentor Books.

-

Zukin, S. (2010), Naked city. The death and life of authentic urban places. Oxford: Oxford University Press. 